\title{
Livelihoods, land use and land cover change in the Zambezi Region, Namibia
}

\author{
Jonathan M. Kamwi ${ }^{1,2}$ - Paxie W. C. Chirwa ${ }^{1}$ • \\ Samuel O. M. Manda ${ }^{3,4}$ - Patric F. Graz ${ }^{5,6}$. \\ Christoph Kätsch ${ }^{1,7}$
}

\begin{abstract}
This paper examines the socio-economic drivers of land use and land cover change and assesses the impacts of such changes to rural livelihoods in the Zambezi region of northern Namibia. We carried out a longitudinal analysis of Landsat imagery of land use and land cover. The analysis revealed that the amount of land in the region covered by forest increased significantly in the period from 1991 to 2010 whilst crop/grass land decreased. Focus group meetings, key informant interviews and semi-structured interviews covering 424 households stratified by gender were used. The results show that natural resource uses are vitally important in the rural livelihoods. The drivers of land use and land cover change are agricultural expansion, population increase and illegal logging. Livelihood coping strategies include piecework, food aid, borrowing from relatives and wild food collection. By gender stratification, piecework contributed 37 and $63 \%$ while
\end{abstract}

Correspondence to: Jonathan M. Kamwi

Mutauk@yahoo.co.uk

1 Department of Plant and Soil Science, University of Pretoria, Private Bag X20, Hatfield, Pretoria 0028, South Africa

2 Ministry of Environment and Tourism, Private Bag 13306, Windhoek, Namibia

3 Biostatistics Unit, South African Medical Research Council, Private Bag X385, Pretoria 0001, South Africa

4 School of Mathematics, Statistics and Computer Science, University of KwaZulu-Natal, Durban, South Africa

5 Department of Land and Property Science, School of Natural Resources and Spatial Sciences, Polytechnic of Namibia, Private Bag 13388, Windhoek, Namibia

6 Present Address: Federation University Australia University Drive, Mount Helen, VIC 3350, Australia

7 Faculty of Resource Management, University of Applied Sciences and Arts Hildesheim/ Holzminden/Göttingen, Göttingen, Germany 
agriculture contributed 29 and $71 \%$ of the income of male- and female-headed households. Logistic regression analysis showed knowledge of regulations, age group and species availability significantly $(p<0.05)$ influenced the choice of a household's livelihood coping strategy. The study concludes that the changes in coping strategies influenced by a variety of factors have led to the diminished use of natural resources. For policy purposes, this suggests that state interventions can play a significant role in promoting more sustainable natural resource usage. This analysis enables effective decision-making to reconcile the efforts of sustainable development and natural resource management.

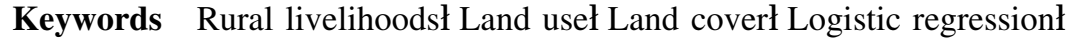
Change detection向 Zambezi

\section{Introduction}

Changes in land use and land cover have serious environmental, economical and social impacts on rural livelihoods in many parts of the sub-Saharan African region (Maitima et al. 2010). This is aggravated by the fact that rural households have to cope with both poverty and variability in climate considering that their livelihood strategies are linked to sectors such as agriculture and forestry that are impacted by climate change. Recurrent droughts and floods are considered to be some of the major factors driving people into poverty and to seek non-farm alternatives to sustain their livelihoods (Shewmake 2008; Akpalu et al. 2008). In addition, livelihoods of rural people are highly dependent on the use of natural resources and services for the supply of basic needs such as food, shelter, medicine and income generation (Shackleton et al. 2007; Kalaba et al. 2010). However, the increasing dependence on the resources may aggravate the pressure on these resources leading to over-exploitation and subsequently deforestation and land degradation (Kalaba et al. 2010). Hence, a deeper understanding of the complex interdependence between changing land use and land cover and rural livelihoods together with coping options is crucial for decision-making.

A livelihood comprises of capabilities, assets, including both material and social resources, and activities, which are mediated by institutional and social relations (Ellis 2000). The combinations of these give rise to the household livelihood strategy. The choice of a livelihood strategy that a household pursues is dependent on the socio-economic characteristics and also on the environmental endowments and entitlements at its disposal. An endowment refers to rights and resources that households have, including land, labour and skills while entitlements refer to social protection in terms of food, income and social networks (Jianchu et al. 2005; Sen 1981). Ellis (2000) further indicates that the livelihood strategy encompasses not only activities that generate income, but many other kinds of elements including social choices. In rural Namibia, particularly the Zambezi region, people are dependent on natural assets that are impacted by changes in land use and land cover. 


\section{Theoretical framework}

Several studies have used the sustainable livelihood approach (SLA) to analyse rural livelihoods (DFID 1999; Ellis 2000). The SLA analyses livelihood based on natural resources and is comprised of five different capitals or assets-human assets, natural assets, financial assets, social assets and physical assets (DFID 1999; Fig. 1). The approach states that within a particular vulnerability context, people deploy livelihood capitals or assets in variable combinations, within circumstances influenced by institutional structures and processes in order to pursue diverse livelihood strategies, with more or less measurable livelihood outcomes. The availability of the endowments and entitlements for livelihoods and the way they are conditioned may be affected by the changes in land use and land cover. According to Filmer and Pritchett (2001), assets provide information on households' structural income status and underlying welfare and are not subject to short-term fluctuations of income and consumption.

While many socio-economic studies based solely on income and expenditure data have been used in developing countries, these are not effective indicators of livelihoods in countries such as Namibia with very high income inequality (Addicott et al. 2003; Werner and Odendaal 2010). Here, we also considered exogenous factors that may impact the availability of natural or environmental resources such as floods, drought and wildlife damage, among others, based on survey results.

Little is known about the impacts of changes in land use and land cover as a function of rural livelihood strategies in the Zambezi region. This is despite the fact that the region is one of the most favourables for agriculture in Namibia. Several studies have been carried out to determine the livelihood diversification activities pursued by rural communities (see Coomes et al. 2004; Ellis and Freeman 2004). However, few of these studies have been undertaken to analyse factors governing communities' decision to pursue different livelihood strategies in Namibia. For instance, Ashley and LaFranchi (1997) carried out assessment of livelihood strategies of rural households in the Zambezi region and their implications for conservancies and natural resource management. Purvis (2002) carried out a study on the livelihoods strategies of communities in eastern Zambezi in order to develop plans and proposals for interventions in the rural environment. However, these

\section{The Sustainable Livelihood Approach (SLA)}

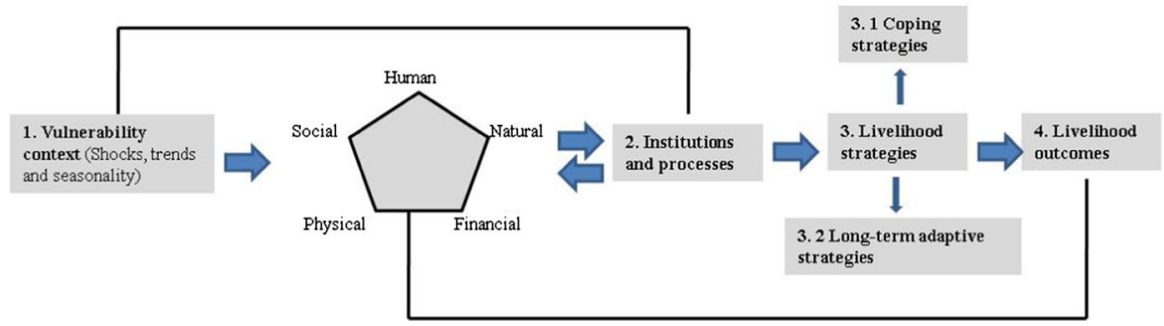

Fig. 1 Sustainable livelihoods approach (adapted from DFID 1991) 
studies did not critically look at the factors that influence the households' choice of the livelihood strategies. This information is particularly important for the design of effective adoption of sustainable livelihood strategies and for assisting communities to cope with the changes in land use and land cover. Therefore, this study aimed to address three key research questions: (1) What are the natural and socio-economic factors that drive the existing land use and land cover? (2) What is the impact of livelihood coping strategies on the use of natural resources? And (3) what factors influence the choice of a household to pursue a particular coping strategy in the area in Namibia?

\section{Research design and methods}

\section{Study area}

Zambezi region is the most wooded in Namibia and is located in the north-east of the country (Fig. 2). The region shares borders with Angola, Botswana, Zambia and Zimbabwe and is divided into six administrative constituencies-Kabbe, Linyanti, Sibbinda, Kongola, Katima Mulilo Urban and Katima Mulilo Rural. The regional capital and administrative centre is Katima Mulilo. For this study, Sibbinda and Kongola constituencies 616,675 ha $(428,678$ ha protected and 187,997 ha

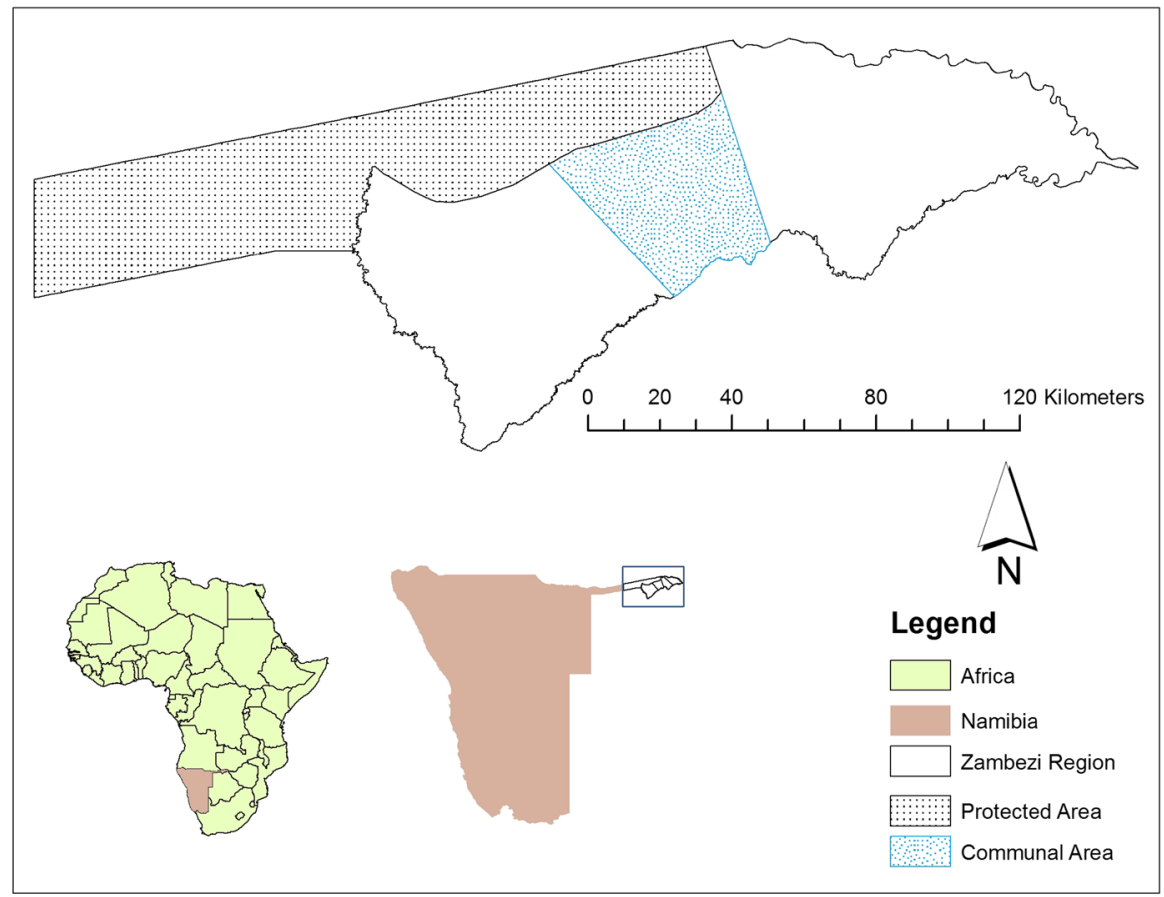

Fig. 2 Location of study area in Zambezi region, Namibia 
communal) were covered. This is because field data for land use and land cover change detection analysis over the years are available to allow for longitudinal and comparative studies. In addition, the area supports rural people most of who are involved in forest-related activities and derive their livelihoods from the natural resources. The Sibbinda and Kongola constituencies share a boundary and are socioeconomically and environmentally relatively homogenous. However, they are administered by different local authorities under the decentralisation programme of the Republic of Namibia. Land tenure operates under a local system organised by the traditional authorities referred to as the "indunas" (Harring and Odendaal 2012).

The population of Zambezi region has been growing steadily since 2000 . In terms of the demographical changes, census results revealed that the Kongola constituency had a population of 4419 people (2237 females and 2182 males) in 2000. In 2010, the population was 5658 (2797 females and 2861 males). On the other hand, the total population in the Sibbinda constituency in 2000 was 9190 (4648 females and 4542 males). In 2010, the total population was 10,182 (5084 females and 5098 males) (Central Bureau of Statistics 2010). The annual growth rate for Kongola was $2.5 \%$ and that for Sibbinda $1 \%$ between the 2000 and 2010 period. The increase in the population growth rates in the Kongola and Sibbinda constituencies is due to the increase in the birth rates and a decrease in the death rates as a result of major medical advances and the increase in health care after independence in 1990 (Central Bureau of Statistics 2010). The increase in the population growth rate may have a differential influence on the land use and land cover due to the need for resources to sustain livelihoods.

The soils in the area are predominantly sandy loam, which is mainly associated with sandy dunes in the western part of the study area (Mendelsohn and Roberts 1997). The vegetation, classified by Giess (1998) as woodland savanna, is predominantly comprised of Baikiaea plurijuga, Guibourtia coleosperma, Pterocarpus angolensis, Burkea africana and Dialium engleranum (Kamwi 2009). The average rainfall of $700 \mathrm{~mm}$ per year in Zambezi is seasonal and variable and relatively abundant compared to the rest of the country.

The agricultural sector, which is dominated by small-scale mixed-crop and livestock farming, is the primary source of livelihood for the majority of the communities (Mendelsohn et al. 2009). Among the major cash crops produced are maize, sorghum, millet and groundnuts. Other off-farm livelihood activities include the collection of non-timber forest products such as the fruit of Vanguelia infausta, Berchemia discolour and Grevia bicolour. The villages in the study are situated in relatively remote areas with poor roads, weak forest extension services but sufficient health and educational facilities (Mendelsohn et al. 2009). Sources of income for the residents include agriculture and business activities that include small stores, selling of thatch grass, poles and part-time job arrangements (referred to as piecework in this study) (Central Bureau of Statistics 2010).

\section{Land use and land cover dynamics}

In order to ascertain whether there have been changes in land use and land cover in the study area, we carried out change detection using multi-temporal Landsat TM 
and ET+ images of 1984, 1991, 2000 and 2010. The images were stratified to differentiate between protected and communal areas. In this study, the communal area was considered as the area that is communally used by rural communities. Standard image pre-processing procedures were used for image composition. Bands 1 through 5 (Landsat TM) and 7 (Landsat ETM +) were considered during image classification. Post-classification change detection procedures were used for land use and land cover change assessment. The analysis provides land use and land cover statistics for a twenty-six-year period (Tables 1, 2, 3).

Land use and land cover change diagnostics showed that forest land decreased during 1984-1991 but increased during 1991-2000 and 2000-2010. Shrub land increased during 1984-1991 and 1991-2000 but reduced during 2000-2010. Crop/grass land increased during 1984-1991 but decreased during 1991-2000 and 2000-2010. These dynamics link well with interview responses where people commonly mentioned that there had been a loss of fields and increased woody cover in the area. It also illustrates that forest lands in the study area are encroaching into crop/grass lands and abandoned crop fields but that these changes were nonpermanent.

\section{Sustainable livelihood approach}

Although the sustainable livelihood approach (SLA) offers the conceptual depiction of the dynamics and interdependence, our empirical analysis of the livelihood strategies examined the static impact of household resource endowments and entitlements. The SLA was applied in this study to assess changes in the livelihood coping strategies. The livelihood strategies, coping and long-term adaptive strategies (boxes 3, 3.1 and 3.2) were our area of interest in the framework. In this case, the choice of a particular livelihood strategy is based on the households' environmental resource endowment and entitlement in terms of the assets.

\section{Sampling framework}

We used the sampling frame that consisted of the village list for each constituency. In each village, we consulted the village headman and knowledgeable community

Table 1 Area changes (ha) of land use and land cover types in the communal area from 1984 to 1991

\begin{tabular}{lrrrrrr}
\hline $\begin{array}{l}\text { Land use/land cover } \\
\text { type }\end{array}$ & $\begin{array}{l}\text { Forest } \\
\text { land }\end{array}$ & $\begin{array}{l}\text { Shrub } \\
\text { land }\end{array}$ & $\begin{array}{l}\text { Bare } \\
\text { land }\end{array}$ & $\begin{array}{l}\text { Other } \\
\text { land }\end{array}$ & $\begin{array}{l}\text { Crop/grass } \\
\text { land }\end{array}$ & Total \\
\hline Forest land & 46,565 & 12,589 & 229 & 1229 & 22,903 & 83,516 \\
Shrub land & 4699 & 6023 & 542 & 116 & 12,705 & 24,085 \\
Bare land & 319 & 629 & 1183 & 17 & 4510 & 6657 \\
Other land & 4607 & 2029 & 5 & 1597 & 15,346 & 23,584 \\
Crop/grass land & 13,656 & 8072 & 651 & 407 & 27,369 & 50,155 \\
Total & 69,845 & 29,342 & 2611 & 3365 & 82,833 & 187,997
\end{tabular}


Table 2 Area changes (ha) of land use and land cover types in the communal area from 1991 to 2000

\begin{tabular}{lrrrrrr}
\hline $\begin{array}{l}\text { Land use/land cover } \\
\text { type }\end{array}$ & $\begin{array}{l}\text { Forest } \\
\text { land }\end{array}$ & $\begin{array}{l}\text { Shrub } \\
\text { land }\end{array}$ & $\begin{array}{l}\text { Bare } \\
\text { land }\end{array}$ & $\begin{array}{l}\text { Other } \\
\text { land }\end{array}$ & $\begin{array}{l}\text { Crops/grass } \\
\text { land }\end{array}$ & Total \\
\hline Forest land & 46,441 & 18,173 & 146 & 446 & 4639 & 69,845 \\
Shrub land & 19,170 & 5569 & 129 & 174 & 4301 & 29,342 \\
Bare land & 385 & 133 & 648 & 20 & 1425 & 2611 \\
Other land & 2067 & 823 & 5 & 157 & 314 & 3365 \\
Crops/grass land & 41,249 & 17,239 & 864 & 1112 & 22,369 & 82,833 \\
Total & 109,313 & 41,935 & 1791 & 1909 & 33,048 & 187,997
\end{tabular}

Table 3 Area changes (ha) of land use and land cover types in the communal area from 2000 to 2010

\begin{tabular}{lrrrrrr}
\hline $\begin{array}{l}\text { Land use/land cover } \\
\text { type }\end{array}$ & $\begin{array}{l}\text { Forest } \\
\text { land }\end{array}$ & $\begin{array}{l}\text { Shrub } \\
\text { land }\end{array}$ & $\begin{array}{l}\text { Bare } \\
\text { land }\end{array}$ & $\begin{array}{l}\text { Other } \\
\text { land }\end{array}$ & $\begin{array}{l}\text { Crop/grass } \\
\text { land }\end{array}$ & Total \\
\hline Forest land & 81,622 & 14,953 & 2295 & 925 & 9518 & 109,313 \\
Shrub land & 26,605 & 6351 & 860 & 2905 & 5214 & 41,935 \\
Bare land & 216 & 339 & 716 & 4 & 517 & 1791 \\
Other land & 1151 & 278 & 86 & 227 & 167 & 1909 \\
Crop/grass land & 11,634 & 5108 & 4490 & 2583 & 9232 & 33,048 \\
Total & 121,227 & 27,030 & 8448 & 6643 & 24,649 & 187,997
\end{tabular}

a Total area of the communal area in the study area is 187,997 ha. Source: Own survey

members to obtain a list of all village households and to identify all households. Random sampling was used to select the villages from the village list. In these villages, we randomly selected households that formed the basic unit of the sample. Within the households, the household head was the unit of observation. Using the FAO (2010) definition, a household is a group of people living together, making common arrangements for food and other essentials for survival. In terms of this definition, a household can include groups in which the people may live in different houses close by but share meals usually prepared in a common kitchen. According to the Central Bureau of Statistics (2014), Kongola constituency consisted of 1226 households and Sibbinda 2376 households in 2011. We conducted semi-structured interviews using a questionnaire in 424 randomly selected households (94 in Kongola and 330 in Sibbinda Constituencies).

\section{Household questionnaire design}

The semi-structured questionnaires which comprised of closed-ended questions and consisted of four sections corresponding to the SLA, namely (1) human assets which included demographical information, (2) financial assets which included the major sources of income, (3) physical and natural assets which included the accessibility and availability of resources and (4) social assets which included information on 
how communities, are linked to social networks in the study area. These sections were aimed at collecting data to characterise rural livelihoods that are impacted by changes in land use and land cover in the study area. The questionnaires were pretested and revised before the actual interviews of the sampled households. The standardised questionnaire was written in English and was translated into local languages (Mbalangwe and Totela), in which respondents were conversant during the interview. Respondents to the survey were not identified either by name or by location to maintain confidentiality. The interviews lasted an average of $45 \mathrm{~min}$. In each household, data on the socio-demographics, shocks and livelihood strategies were collected using a questionnaire. The survey was administered in the period March-April 2013.

\section{Focus group and key informant discussions}

One focus group meeting was carried out in Kongola and two in Sibbinda constituencies. These meetings consisted of 25-30 discussants and were helpful in triangulating the household interviews to provide a detailed understanding of their livelihoods. Three villages were selected for focus group discussions considering the differential remoteness of the villages in the constituencies. The villages selected were Singalamwe (Kongola constituency), Sibbinda and Cinchimane (Sibbinda constituency). Focus group meetings included an equal number of men, women and youths who utilise different land resources to sustain their livelihoods. In particular, focus group meetings discussed issues such as the use of natural resources, shocks, operations of social networks, livelihood strategies and the available coping options under the changing land use and land cover in the area. The meetings lasted for about $80 \mathrm{~min}$ and were facilitated by the researchers. A checklist that included detailed questions on the livelihoods was used to achieve focused discussions. In addition, three in-depth key informant discussions were conducted in the same villages as in focus groups to provide in-depth information about the rural livelihoods and perceived changes in land use and land cover. Key informant checklists covered similar themes as for focus groups but included a more detailed additional focus on the social structure within the villages to triangulate the semistructured interviews (Kasemir et al. 2003). In our case, key informants were village leaders and other elderly members of the community with an average age of 60 years. This included 15 people (8 females and 7 males) in the Kongola constituency and 25 people (13 men and 12 women) in Sibbinda constituency who had lived in the study area throughout their lives and are knowledgeable about the dynamics in land use and land cover.

\section{Data collection and analysis}

Household surveys were conducted face to face with household heads (or another senior household member in their absence) to collect general household socioeconomic data (demographics, assets and land use) and qualitative information about forest use, coping strategies, shocks and vulnerability. The accuracy of the data was checked by frequency counts of each rural household and category. 
Questionnaire data were processed and coded using the Statistical Package for Social Sciences (SPSS) software version 19 and subjected to further analysis. Descriptive statistics were used to characterise land use and land cover and socioeconomic variables. The Pearson's Chi-square analysis was used to determine associations between socio-demographical variables and coping strategies. However, in order to identify variables that were independent predictors of various main coping strategies, a series of logistic regressions were fitted from which the estimated odds ratios $(y)$ were derived to ascertain the effect of the predictors on the livelihood coping strategies. Odds ratios were used to measure the magnitude of strength of association or non-independence between two binary data values. In this case, we quantitatively assessed the relative importance of a number of predictor variables. Content analysis was used to analyse qualitative data, whereby the discussions from the focus group and key informants were objectively and subjectively analysed (Hsieh and Shannon 2005).

\section{Specification of the logistic regression model}

In order to identify the determinants of the rural household decision to employ various livelihood coping strategies to the changes in land use and land cover, we assumed that a rational rural household will choose among the four mutually exclusive livelihood coping strategies which offer the maximum utility. For each of the coping options, the household was categorised as either equal to 1 if that household had opted for the livelihood coping option and 0 if that household had not opted for the livelihood coping option. Thus, in a household, the sum of this variable ranged from 0 to 4 , depending on the number of coping mechanisms indicated. We could analyse this using standard linear regression, but that would mean that the probability of households to pursue a specific livelihood coping option may become greater than one and less than zero as the number of explanatory variables increases and these are theoretically and practically inadmissible in our case. Therefore, in this paper we took each indicator as a binary outcome and used logistic regression to model a number of explanatory variables including (1) gender (male $=1$; female = 2); (2) age; (3) education; (4) species availability (yes = 1; no =0); (5) participation in development activities (yes $=1$; no $=0$ ); and (6) affected by shocks (yes $=1$; no $=0$ ). The age and education variables were categorised as follows: age: 18-25; 26-50; and 51-93 and education: grade 1-7; 8-12; and never attended. In the logistic regression analyses, dummy variables were constructed for these categories with the last category used as a reference. Livelihood coping strategies (dependent variables) used for modelling are as follows: (1) piecework; (2) wild food collection; (3) food aid; and (4) borrowed from relatives. The Chisquare test at $\alpha=0.05$ significance level was used to assess the goodness of fit of the models. Coping strategies such as selling of timber, selling of firewood, did nothing and other were not included in the logistic regression model because they were mentioned by few respondents, which made them insufficient for inclusion in the model. 


\section{Results}

\section{Demographical and economical characteristics of the sample population}

The sample survey result indicated an average rural household in the study area consists of five people. Household heads were $29 \%(n=124)$ male and $71 \%$ $(n=300)$ female. Within the households interviewed, $25 \%(n=105)$ of the respondents attended grade $1-7$ and $55 \%(n=233)$ grade $8-12$ and were literate, as understood by their ability to read and write. However, $20 \%(n=86)$ of the respondents never attended school. With respect to their marital status, $56 \%$ $(n=238)$ of respondents were married, $27 \%(n=116)$ single and $17 \%(n=70)$ widowed or separated. Most respondents have access to potable drinking water with $82 \%(n=346)$ of the respondents obtaining it within $500 \mathrm{~m} ; 14 \%(n=60)$ within $500 \mathrm{~m}-1 \mathrm{~km}$; and $4 \%(n=18)$ more than $1 \mathrm{~km}$, respectively.

\section{Sources of income}

Piecework was ranked to be the most important source of income in the study area (1.24) (see Fig. 3). Income from agriculture constituted the second highest ranked source (1.12). Other income sources such as the opportunistic sale of fish, reeds or thatching grass were the third most important income source (1.10). Although the majority of households were headed by females who are married, the remittances from their partners living away from home were ranked low (0.01) compared to other sources of income.

With respect to the tendency of respondents to choose a diversity of income sources, the influence of gender was significant $(p<0.05)$. About $29 \%$ of male respondents ranked agriculture as the priority source of income compared to their female counterparts $(71 \%)$. The results further revealed that selling of poles is an important source of income for men $(71 \%)$ and less important for women $(29 \%)$. In addition, $63 \%$ of women respondents considered piecework as an important source of income compared to their male counterparts (37\%). Small businesses

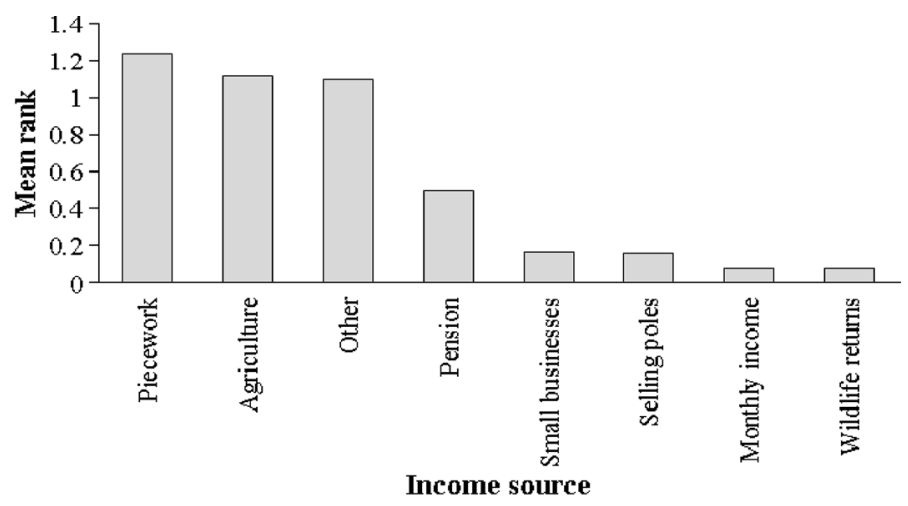

Fig. 3 Sources of income in the study area by ranks 
were also considered important source of income for women $(58 \%)$ in relation to men $(42 \%)$. Also considered important was pension or death benefits as reported by women $(77 \%)$ compared to men $(23 \%)$.

\section{Skills}

Figure 4 shows frequency of skills mentioned by respondents. Cropping and livestock rearing were the most frequent skill mentioned, and there were no significant differences between male and female $(p>0.05)$ respondents.

\section{Forest resource dependence and land use}

As part of the understanding of the level of dependency on forest resources, rural household heads were asked to rank their main important forest products. Figure 5 shows that poles constitute the most important forest product in the study area (1.29), followed by firewood (1.03). The most preferred species for firewood by rank included species such as Acacia erioloba and Combretum collinum (1.34); Terminalia sericea (0.47); Colophospermum mopane (0.29); and Baikea plurijuga (0.20). Grass and reeds were ranked the third important forest product (1.20). The harvesting of tubers, more especially, the devil's claw (Harpagophytum procumbens), for sale was the lowest ranked forest product (0.02). Thirty-eight per cent (38\%) of the respondents comprising 50 males and 110 females indicated that they trade in forest products, particularly during critical periods including the hunger season (dry season) between October and February.

Furthermore, gender seemed to influence preference for some forest products, since among men and women poles were considered a more important forest product ( $86 \%$ for males compared to only $14 \%$ of their female counterparts $(p<0.05))$. In the study area, it is a duty of men to cut poles for home construction or for sale. However, harvesting of thatching grass and reeds was found to be

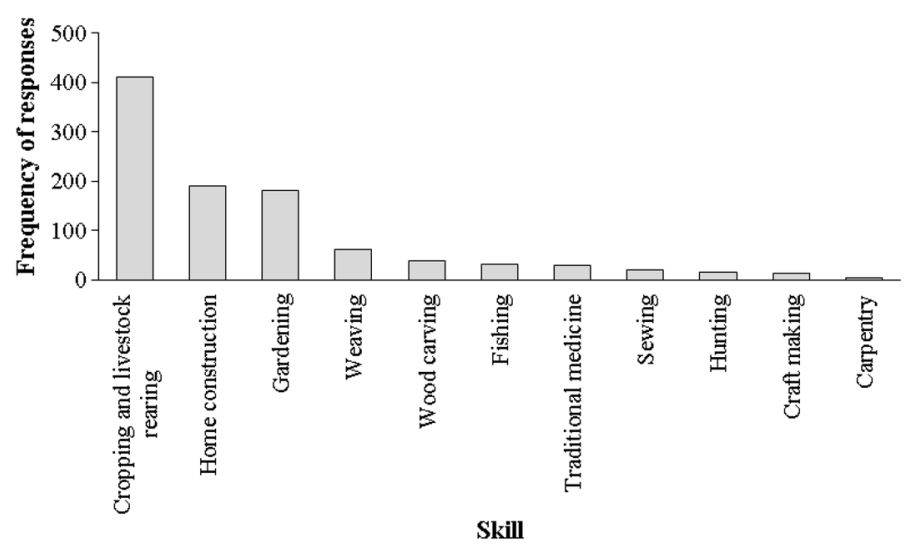

Fig. 4 Frequency of skills possessed by respondents in the study area 


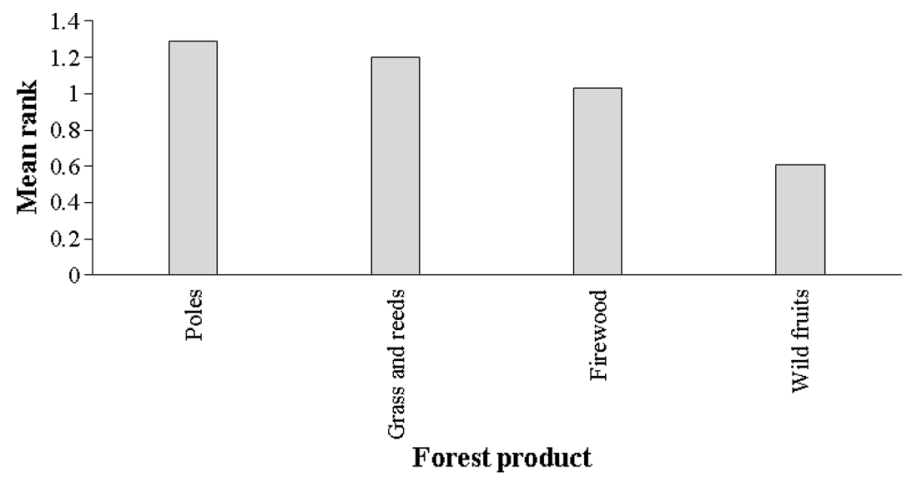

Fig. 5 Important forest products by ranks

equally important for both men and women as a seasonal activity that provides income. As expected, firewood was the most important forest product for women (72\%). This is mainly used as energy for daily cooking by women.

The results also highlighted that apart from settlements, cropland is an important form of land use in the Zambezi region. In terms of the usage of their land, settlements were the highest ranked use of the land (1.81) compared to crop farming (1.12), vegetable gardening (0.88) and grazing (0.79). Of note is the fact that grazing lands constitute multiple land use categories since the land is under communal administration. Crop farming is mainly practiced by female-headed households $(73 \%)$ compared to their male counterparts $(27 \%)$.

\section{Communities' perceptions on the causes of land use and land cover change}

Figure 6 shows that there is a general understanding that agricultural expansion is leading to changes in land use and land cover in the study area (1.02). Population increase was ranked as the second most important driver of land use and land cover

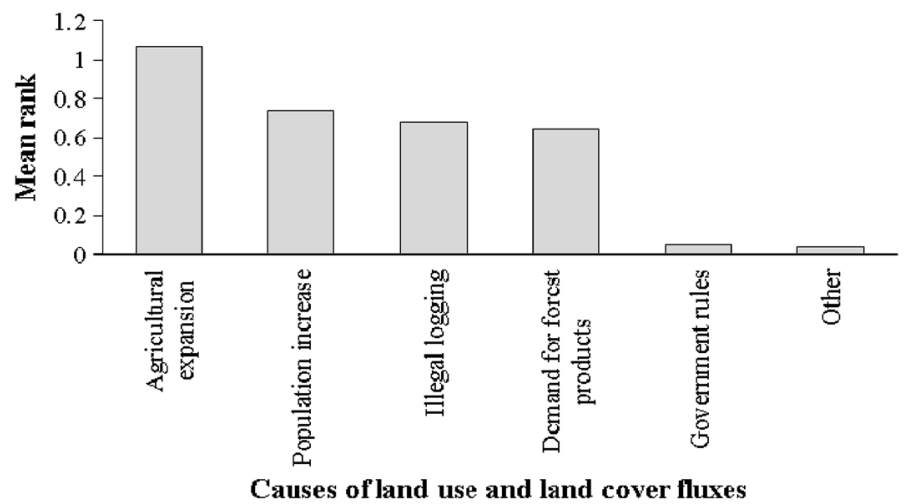

Fig. 6 Drivers of changes in land use and land cover by ranks 
change (0.74), with illegal logging (0.65) and high demand for forest resources (0.65) ranked third and fourth, respectively. Other drivers such as wildlife damage and forest fires were considered of little importance (0.04). When asked to rank the effect of underlying and proximate drivers of land use and land cover in their areas, discussants in the focus group meetings indicated that the indirect or underlying drivers of land use and land cover such as socio-economic policies are important because they lead to the physical actions, which have an impact on land use and land cover. In the words of one focus group member, "when I heard that the Government will pay for ploughing costs of my crop field, I decided to expand it by clearing the adjacent forest land". Some also said that the establishment of community forests in their areas as initiatives to ensure equitable distribution of benefits has led to the reduction in illegal harvesting of forest resources.

\section{Social networks}

The pooled results show that $38 \%$ of the respondents participated in development activities in the study area. Respondents received assistance in terms of planting their crops through extension services and $68 \%$ participated in development activities such as fruit tree planting and fire fighting. In terms of gender differentiation, there was no significant difference in gender participation among the respondents $(p>0.05)$.

\section{Shocks}

Shocks are an important source of vulnerability of rural households and were reported for the previous 5 years during the study. In the present study, covariate shocks such as irregular rainfall (1.70), droughts (1.53), fire (1.28\%) and food shortages (1.24) were the most highly ranked shocks by respondents (Fig. 7).

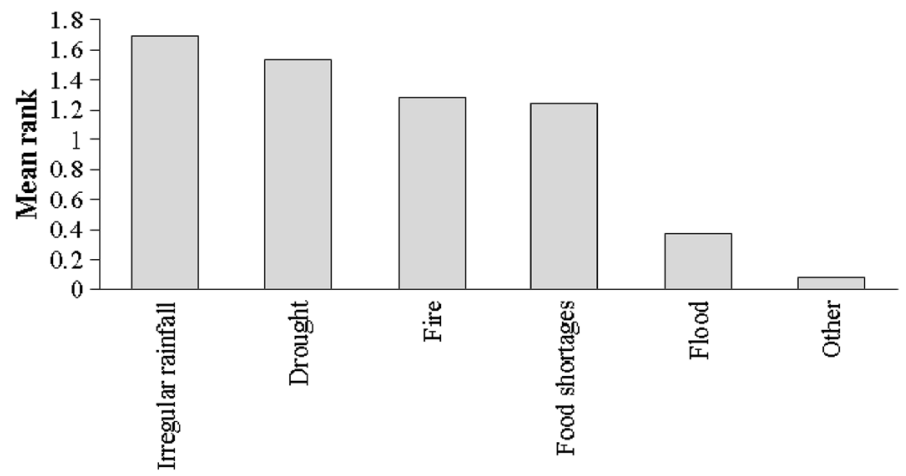

Shock

Fig. 7 Type of shocks reported during the past 5 years by ranks 


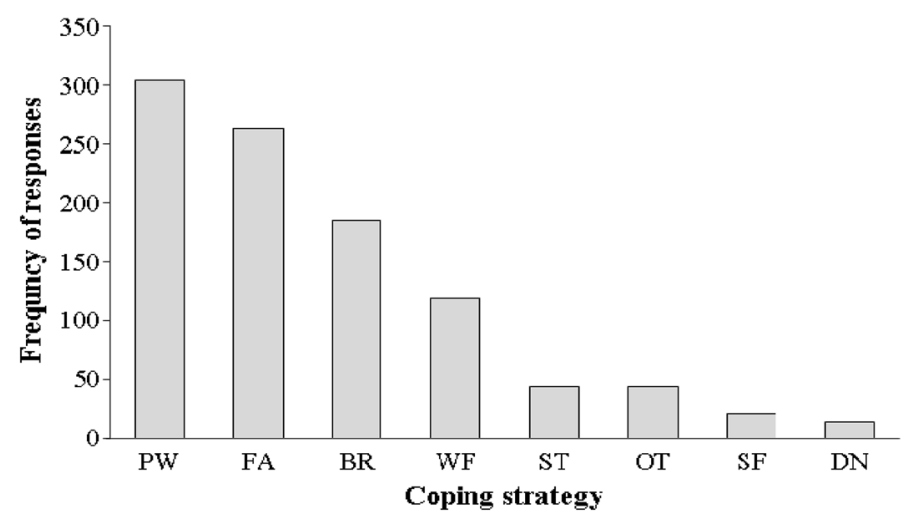

Fig. 8 Type of shocks reported during the past 5 years. $P W$ piecework, $F A$ food aid, borrowed from relatives, $W F$ wild food harvesting, $S T$ selling timber, $O T$ other, $S F$ selling firewood, and $D N$ did nothing

\section{Livelihood coping strategies}

Figure 8 shows that the most prominent coping strategy $(n=304)$ was by engaging in piecework activities. Food aid which is provided by the government was also reported by many respondents $(n=264)$ as a coping strategy to shocks. A total of 186 respondents indicated that they cope by borrowing from relatives; 119 collected wild food to fill food deficits; 44 sold timber and carried out other activities such as selling fish and garden produce; and 21 sold firewood to supplement their income.

However, only 13 of the respondents did nothing in response to shocks. By comparison, no significant differences were found between genders and did nothing, piecework, collecting wild food, receiving food aid, borrowing from relatives and other livelihood coping strategies $(p>0.05)$. However, significantly more men $(95 \%)$ sold timber $(p<0.05)$ than women $(5 \%)$. Significant differences were found between genders with respect to the selling of firewood $(p<0.05)$. Approximately $71 \%$ of men sold firewood compared to women (29\%).

Significant differences between age groups (18-25, 26-50 and 51-93) and the participation in piecework activity were found $(p<0.05)$. This activity was more important for age groups 51-93 (49 \%) and 26-50 (31\%). Although no significant differences were found between selling of timber and poles $(p>0.05)$, the strategy is more important for respondents in the age range 51-93. Borrowing from relatives was found to be significantly different among the age groups $(p<0.05)$. In particular, respondents aged 51-93 (48 \%) considered borrowing as an important coping strategy.

\section{Determinants of livelihood coping strategies}

The results of the logistic regression analysis of coping strategies adopted by rural households are provided in Table 4. 
Table 4 Factors affecting the choice of households to pursue specific livelihood coping strategy

\begin{tabular}{|c|c|c|c|c|c|}
\hline Coping strategy & Independent variable & Odds ratio & Lower & Upper & $p$ value \\
\hline \multirow[t]{8}{*}{ Participated in piecework } & Regulations knowledge & 2.286 & 1.393 & 3.753 & 0.001 \\
\hline & Species availability & 0.893 & 0.503 & 1.583 & 0.699 \\
\hline & Education level (grade 1-7) & 1.171 & 0.595 & 2.303 & 0.647 \\
\hline & Education level (grade 8-12) & 1.121 & 0.579 & 2.172 & 0.734 \\
\hline & Never attended & (1) & & & \\
\hline & Age group years (18-25) & 0.161 & 0.057 & 0.457 & 0.001 \\
\hline & Age group years (26-50) & 0.396 & 0.21 & 0.745 & 0.004 \\
\hline & Age group years (51-93) & (1) & & & \\
\hline \multirow[t]{8}{*}{ Collected wild food } & Regulations knowledge & 21.293 & 7.601 & 59.645 & 0.000 \\
\hline & Species availability & 0.968 & 0.547 & 1.714 & 0.912 \\
\hline & Education level (grade 1-7) & 1.089 & 0.503 & 2.356 & 0.829 \\
\hline & Education level (grade 8-12) & 0.817 & 0.400 & 1.667 & 0.578 \\
\hline & Never attended & (1) & & & \\
\hline & Age group years (18-25) & 0.566 & 0.294 & 1.088 & 0.088 \\
\hline & Age group years (26-50) & 0.888 & 0.484 & 1.629 & 0.702 \\
\hline & Age group years (51-93) & (1) & & & \\
\hline \multirow[t]{8}{*}{ Food aid } & Regulations knowledge & 2.898 & 1.818 & 4.621 & 0.000 \\
\hline & Species availability & 0.521 & 0.299 & 0.906 & 0.021 \\
\hline & Education level (grade 1-7) & 0.516 & 0.270 & 0.985 & 0.045 \\
\hline & Education level (grade 8-12) & 0.402 & 0.216 & 0.750 & 0.004 \\
\hline & Never attended & (1) & & & \\
\hline & Age group years (18-25) & 1.777 & 0.904 & 3.493 & 0.096 \\
\hline & Age group years (26-50) & 1.952 & 1.111 & 3.431 & 0.020 \\
\hline & Age group years (51-93) & (1) & & & \\
\hline \multirow[t]{8}{*}{ Borrowed from relatives } & Regulations knowledge & 10.454 & 5.870 & 18.618 & 0.000 \\
\hline & Species availability & 0.500 & 0.287 & 0.870 & 0.014 \\
\hline & Education level (grade 1-7) & 1.042 & 0.519 & 2.095 & 0.907 \\
\hline & Education level (grade 8-12) & 0.713 & 0.371 & 1.369 & 0.309 \\
\hline & Never attended & (1) & & & \\
\hline & Age group years (18-25) & 0.782 & 0.405 & 1.512 & 0.465 \\
\hline & Age group years (26-50) & 0.760 & 0.428 & 1.350 & 0.349 \\
\hline & Age group years (51-93) & (1) & & & \\
\hline
\end{tabular}

The output of the logistic regression model revealed that after adjusting for the effect of the factors, there is a significant influence of knowledge of regulations and shocks $(p<0.001)$ and was associated with high uncertainty $(y>1)$. Level of education showed no significant influence when choosing the collection of wild food as a coping strategy $(p>0.05)$. However, although no significant influences were found among the grade 8-12 education level compared to those who never attended school, the odds ratios increased by a factor of 1.066. Despite the absence 
of significant influences $(p>0.05)$ between the age groups of 18-25 and 26-50 compared to the 51-93 in the choice of the collection of wild food coping strategy, the odds ratio was high by factors of 1.834 and 1.146, respectively. Knowledge of regulations was found to significantly influence the collection of wild food $(p<0.05)$ and was also associated with high uncertainty $(y>1)$. Although species availability significantly influenced the choice of receiving food aid $(p<0.05)$, it was associated with low uncertainty $(y<1)$. Knowledge of regulations and shocks was found to significantly influence the choice of receiving food aid $(p<0.05)$ and was also associated with high uncertainty. Borrowing from relatives was found to be significantly influenced by knowledge of the regulations $(p<0.05)$ and was also associated with high uncertainty $(y>1)$.

\section{Discussion}

\section{Land use and land cover changes}

The remote sensing and rural household interview results confirmed that land use and land cover changes have been ongoing during the study period, but reached a noticeable peak, particularly the expansion of the forest land between 1991-2000 and 2000-2010. This coincided closely with the national independence of Namibia in 1990, which brought sustainable management of forests and policy transitions aimed at protecting natural resources. The magnitude of the changes in land use and land cover reported here is likely to be influenced by the highly heterogeneous, mosaic and complex spatiotemporal characteristics of land use and land cover of the study area. Furthermore, the Landsat images used may only depict the changes in the landscape beyond the $30-\mathrm{m}$ resolution, indicating that changes less than $900 \mathrm{~m}^{2}$ thresholds may not be detected. However, marginal changes in land use and land cover are expected not to cause a considerable impact in the rural livelihoods since there are other interacting socio-economic and biophysical factors that may drive such changes. This study indicated that the majority of respondents perceived forests and woodlands to be expanding. While these responses do not identify specific changes in the day-to-day activities of focus group members, they point to changes in their livelihoods coping strategies among their households as a result of the changes in land use and land cover. One of the female respondents said "if I do not have natural resources around my village, I must make sure that my children continue to eat and go to school by carrying out other businesses". The perceived expansion of forest land also confirms the findings from the analysis of satellite images.

Expansion of forest land may in part also be attributed to the establishment of communal conservancies in the study area. The decrease in crop/grass land after independence in 1990 was also due to the increase in socio-economic opportunities, and men, in particular, moved from rural areas to towns in search of formal employment and education. This resulted in a substantial reduction in agricultural labour in the villages (Central Bureau of Statistics 2001; 2012). 
Under the conservancy setting, local people use natural resources sustainably through modern business principles. The benefits derived from the sale of wild animals, jobs, training opportunities and the acquisition of new skills are shared equitably. Similarly, in Botswana, the Natural Resources Management Programme (NRMP) has decentralised wildlife management by bestowing appropriate authority on Rural District Councils (RDCs) and District Land Boards (DLB), in which communities can obtain the right to engage in resource utilisation in controlled hunting areas by fulfilling requirements (Simasiku et al. 2008).

During the focus group discussions, discussants pointed out that the extension of forest land was negative from the agricultural perspective because it was associated with increasing populations of wild animals through creation of conservancies, which created problems for crop production (human-wildlife conflict). One of the male discussants said "animals roaming around our area destroys our crops during the cropping seasons without a fair compensation from the Government and are extremely dangerous". This is in line with Fernández (2010) who found that households around Zambia Game Management Areas are more likely to suffer crop loss due to wildlife, an unresolved conflict that needs further exploration.

In a positive light, respondents viewed the increase in forest land as a readily available source of non-timber forest products, which are used to sustain rural livelihoods. While the agricultural policy may encroach upon community-based natural resource management activities, it can be compatible with its goals (Corbett and Daniels 1996). The promulgation of the Forest Act, 2001 (Act No. 12 of 2001), and the promulgation of the Forest Amendment Act, 2005 (Act No. 13 of 2005), support the declaration of community forests through which a community management structure has a responsibility. Through the community forest initiative, different land use zones may be identified thus assisting in the regulation of land clearing.

\section{Drivers of land use and land cover changes}

Overall, agricultural expansion was ranked as the most predominant driver of land use and land cover in the study area. This was followed by population increase, which was ranked the second driver of land use and land cover change. This is reinforced and perpetuated by the widely referenced investigations which put the neo-Malthusian concept into perspective (Lambin 1997; Harrison 1992). Focus group discussants said that the proximate drivers of forest land increase were the reduction in forest and wood land use, increased rainfall in the area, and change in land use practices due to human migration to Katima Mulilo and other towns in the country in search of employment opportunities. One of the discussants summed up the general opinion of the group by explaining, "we now carry out other activities such as harvesting Harpagophytum tuber species and other non-wood forest products to improve our lives, not just cutting trees". Another said "we have received good rains during the past years and our village is getting empty because people continue to move to Katima Mulilo to look for jobs".

With regard to agricultural land decline, the reduction in cattle numbers including loss of draught oxen for ploughing was the most common reason 
mentioned for the abandonment of crop farming. This may have also resulted in reduced browsing and trampling which may have increased the recruitment of regenerating woody plants. Although the increase in government social grants was not mentioned as a driver of field abandonment in the Zambezi region, it is plausible to consider it as a further driver of reduced crop farming since people have access to other non-agricultural sources of income. This finding is congruent with a worldwide review by Benayas et al. (2007) who showed that globally, field abandonment is more commonly driven by socio-economic factors than ecological ones, as reflected by this study.

\section{Skills}

In terms of capacity to pursue different livelihood coping strategies, respondents were asked to list skills available in their households. Our expectation was that a combination of skills enables men and women to access new opportunities for income generation to improve livelihoods. Other prominent skills mentioned include home construction and gardening, both of which are part of the culture. Skills such as weaving, wood carving, fishing, traditional medicines, sewing, hunting, craft making and carpentry are flexible and easy to fit in at home. Hence, communities choose to continue to employ them, despite lower returns (LaFranchi 1996). There is enormous variation in the ability of households to grow sufficient food, as it is constrained by rainfall and drought, access to cattle for draught power and the availability of labour at the peak of the cropping season (Ashley and LaFranchi 1997). This may influence the usage of natural resources due to changes in the composition of household labour. The labour force participation rate which is defined as the proportion of economically active people in a given population group was very low in Sibbinda (29.2\%) and $58.4 \%$ in the Kongola constituencies (Central bureau of Statistics 2011).

\section{Natural resource use}

Among the important forest products, poles and firewood were the most important in the study area. This is in agreement with the earlier findings of Ashley and LaFranci (1997) who found that rural communities in the Zambezi region use poles for household construction and firewood as the main source of energy on a daily basis. In this case, households that use these products for direct consumption may save their scarce cash resources, which would have otherwise been used to purchase the products (Shackleton and Shackleton 2004). However, gender seemed to influence preference for some forest products, since among men and women poles were considered a more important forest product for males compared to their female counterparts who ranked firewood most important. In the study area, it is a duty of men to cut poles for home construction or for sale and for women to collect firewood for cooking. The felling of trees for firewood and the collection of firewood from moribund trees have been widely reported and may contribute to the changes in land cover (Alelign et al. 2011; Chirwa et al. 2008; Shackleton and Shackleton 2004). 
The present study indicates that harvesting of thatching grass and reeds was equally important for both men and women as a seasonal activity that provides income. This is in contrast to the previous findings in the tropical dry forests of Nigeria (Gbadegesin 1996). Our findings, however, are congruent with those of Paumgarten and Shackleton (2009), who observed negligible gender effects on forest use in South Africa. Furthermore, the number of residents using natural resources particularly poles in our study may actually be higher than reported due to the failure of study participants to disclose their use for fear of prosecution. According to the Forest Act 2001 (Act No. 12 of 2001), and the Forest Amendment Act 2005 (Act No. 13 of 2005), permits from the Forestry Department or local authorities are required for the harvesting of trees (Government Gazette of the Republic of Namibia 2001, 2005).

\section{Social networks}

In terms of Namibia's decentralisation policy of 1993, regional councillors are expected to establish development committees in their constituencies (Jones 2001). Below the constituency level, villages and settlements are also expected to establish development committees. These social networks are important in rural livelihoods because they provide land use and land cover information aimed at improving rural livelihoods and early warnings of shocks to large audiences at the same time. Interview results have shown that communities have been assisted to plant trees to sustain their livelihoods through fruit production and to establish woodlots to alleviate the shortage of firewood still the main source of energy for cooking. Furthermore, social networks basically consist of membership in more formalised groups, networks and connectedness, and relationships of trust, reciprocity and exchanges (Steimann 2005). Other essential networking structures in the study area comprised community forestry committees, conservancy committees, water point committees and associations.

\section{Shocks}

The prominent shocks mentioned in our study include the irregular rainfall, droughts, fire and food shortages. Our results are similar to those of Dercon et al. (2005) who indicated that in Ethiopia, more than $50 \%$ of surveyed households reported drought and consequently food shortages as the most important shocks. Due to the prevalence of these shocks in the Zambezi region, the Namibian government has implemented response measures. Although these shocks affect communities as a whole, households differ in their ability to recover from the consequences of such shocks. In this case, rural households with limited assets and skills for other survival strategies are less likely to recover from the shocks. 


\section{Livelihood coping strategies}

Rural households in the Zambezi region engage in various livelihood coping strategies. The prominent coping strategies were piecework, wild food collection, food aid and borrowing from relatives. These coping strategies are consistent with those mentioned by Ashley and LaFranchi (1997) in the Zambezi region. Virtually, all households rely on a combination of these livelihood coping strategies as a means of survival. Although no quantitative assessment of borrowing was done, it was estimated that the income from family members working outside the area was quite substantial. This is consistent with CSO (1996) who reported that remittances constituted about $2 \%$ of household income in the Zambezi region. Other livelihood coping strategies mentioned included the selling of timber, selling of firewood and other (opportunistic sale of fish and reeds). Although there was no significant influence of education $(p>0.05)$ on the main coping strategies in our study, education may affect the choice of coping strategy through increased access to information about the potential costs associated with different kinds of coping strategies. Numeracy skills may provide individuals with greater understanding of opportunity costs of undertaking a specific coping strategy over others (Rashid et al. 2006).

In terms of age differentiation and the choice of piecework as a coping strategy, the study showed that piecework was an important activity for the age groups 26-50 and 51-93. In Namibia, age groups 18-25 rarely participate in piecework due to the fact that they are required to attend school or to pursue tertiary education. The Namibian government introduced free primary education in 2013 and intends to introduce free secondary education in the future. More than half of households surveyed received government drought relief through the food aid programme. This may be seen as a rational response on the part of government to the higher levels of drought in the study area.

Female-headed households tended to borrow more frequently with more than half of the respondents reporting borrowing livelihood amenities such as money and food, twice the proportion among male-headed households.

\section{Determinants of coping strategies}

Education is regarded as one of the most important contributors of more remunerative salaried and skilled employment in rural Africa (Barrett et al. 2001). Thus, education paves a way for better-paid job opportunities that requires formal schooling. Our study revealed that normal employment opportunities that constitute a consistent monthly income were not considered a major source of livelihood. This is also consistent with data from the national census that showed high levels of unemployment in the region. Based on the logistic regression results, the odds ratio increased for the grade 8-12 education level. This is because education gives insights on how to cope and diversify livelihood options to attain better lives. The possible explanation is that the average education achieved (which is grade 8-12) by the sample households is not sufficient to be formally employed. This is consistent with the findings by Berhanu (2006) for all of sub-Saharan Africa. 
In our case, the knowledge of regulations encompasses a range of issues such as participation, power and authority, governance, laws and social relations. This in turn determines the livelihood options people are able to pursue. The results of the present study showed that the knowledge of regulations significantly influenced the choice of pursuing the predominant livelihood coping strategies (piecework, collection of wild food, receiving food aid and borrowing from relatives). The knowledge of the provisions of the forest policy significantly influenced the collection of wild food. The Namibian programme of community-based management of natural forests involves the participation of rural communities in sustainable forest management that provides them with ownership and tenure rights of forest resources to reduce levels of malnourishment. This programme played a significant role in promoting the sustainable utilisation of natural resources and, at the same time, increased the regeneration of natural forests in the Zambezi.

Knowledge of regulations enables rural households to participate in piecework activities legally to generate income through access to information and innovation. Based on the focus group discussions, the participation in piecework provides knock-on effects on the ability of rural households to pay for other needs and to provide important livelihood components, for example, purchasing of clothes. Furthermore, the knowledge of regulations enables rural communities to be aware of their rights in terms of food aid. Over the past 10 years, Namibia undertook the drought relief programme to sustain the livelihoods of communities affected by drought. These alternatives are usually provided through agricultural extension services and other social networks such as village development committees. Compared to the 51-93 age groups, the 18-25 and 26-50 age groups are more likely to collect wild food. This is due to longer distances that need to be travelled to collect the wild food, an activity which may be difficult for elderly people.

\section{Conclusions and perspectives}

This study has provided insights into the livelihoods and coping strategies amongst rural communities of the Zambezi region, namely the extent to which these strategies influence land usage and the exploitation of natural resources. In addition, it provides an understanding of the relative importance of natural resources to rural livelihoods in different local contexts, as well as the differentiation of the use of resources in relation to household gender, age and education level to provide new insights into the complex dynamics between sustainable livelihoods and natural resource usage. There are substantial differences in livelihood coping strategies, according to whether individuals are male or female, old or young, literate or illiterate. Furthermore, this study has revealed that there are linkages between the socio-economic and ecological factors that derive the fluxes of land use and land cover in the Zambezi region. In this case, three key conclusions on the linkages between rural livelihoods and land use and land cover can be made for the Zambezi region. Firstly, the existence of ecosystem services provides opportunities to derive a means of livelihood in the study area. Indeed, hundreds of the residents of the 
Zambezi derive direct benefits from forests, forestry and forest products. These benefits are of paramount importance during the periods of shocks. Secondly, rural livelihoods in the Zambezi are diverse, and most households do not rely on a single livelihood coping strategy. Thirdly, further conceptual scrutiny and data gathering are required to enable researchers to better explain the driving force in the communities' behaviour in the context of land use. The limitation of such a mission lies, in part, in the lack of data over long time periods.

Environmental policies in Namibia seem to be informed by poverty alleviation and the equitable sharing of benefits of environmental resources. However, minor tensions among policies aimed at conservation and protection of forests and forest resources exist, thereby putting the country in a predicament of criminalising the unsustainable use of resources on the one hand and, on the other hand, wishing to support livelihoods by promoting access to these resources by communities. Our study contributes to the growing literature on the drivers and effects of land use and land cover changes on rural livelihoods, by providing empirical evidence from the dry forests of southern Africa. The study also confirms the high reliance of rural livelihoods on natural resources and highlights the susceptibility of rural communities to changes in land use and land cover. Similar case studies should be conducted across the various regions of Namibia and dry woodlands of southern Africa in general to understand how local socio-economic factors impact land use and land cover to inform sound decisions for sustainable land management practices.

Acknowledgments Thanks are due to the communities of Kongola and Sibbinda constituencies in the Zambezi region for sharing their livelihood experiences with us. This research was supported by the University of Pretoria and the Ministry of Agriculture, Water and Forestry in Namibia. We are also grateful for the financial support from the Southern African Science Service Centre for Climate Change and Adaptive Land Management (SASSCAL). Last but not the least, we would like to express our appreciation to the Forestry extension officers in the Zambezi region and all organisations and individuals who provided the necessary support and secondary data. This research complies with the current laws of the Republic of Namibia.

\section{References}

Addicott, S., Freeman, B., \& Kelly, M. (2003). Socio economic study of the forest industries in Central Victoria. Report No. 42068-003. Central Victorian Farm Plantations Committee.

Akpalu, W., Hassan, R. M., \& Ringler, C. (2008). Climate variability and maize yield in South Africa: Results from GME and MELE methods. IFPRI Discussion Paper No. 843.

Alelign, A., Yemshaw, Y., Teketay, D., \& Edwards, S. (2011). Socio-economic factors affecting sustainable utilization of woody species in Zegie Peninsula, northwestern Ethiopia. Tropical Ecology, 52(1), 13-24.

Ashley, C., \& LaFranci. (1997). Livelihood strategies of rural households in Caprivi: Implications for conservancies and natural resource management. Research Discussion Paper No. 20. Directorate of Environmental Affairs. Ministry of Environment and Tourism. Namibia.

Barrett, C. B., Reardon, T., \& Webb, P. (2001). Non-farm income diversification and household livelihood strategies in Rural Africa: Concepts, dynamics, and policy implications. Food Policy, 26, 315-331.

Benayas, J. M. R., Martins, A., Nicolai, J. M., \& Schulz, J. J. (2007). Abandonment of agricultural land: An overview of drivers and consequences. Perspectives in Agriculture, Veterinary Science, Nutrition and Natural Resources, 2, 2-14. 
Berhanu, A. (2006). Effective aid for small farmers in Sub-Saharan Africa: Southern civil society perspectives. Addis Ababa: Canadian Food Security Policy Group.

Central Bureau of Statistics. (2001). 2001 population and housing census-National report. Windhoek: Central Bureau of Statistics.

Central Bureau of Statistics. (2010). An atlas of Namibia's population: Monitoring and understanding its characteristics. Windhoek: Central Bureau of Statistics.

Central Bureau of Statistics. (2011). Namibia 2011 population and housing census preliminary results. Windhoek: Central Bureau of Statistics.

Central Bureau of Statistics. (2014). 2011 population and housing census: Zambezi regional profile. Namibia: Windhoek.

Chirwa, P. W., Syampungani, S., \& Geldenhuys, C. J. (2008). The ecology and management of the Miombo woodlands for sustainable livelihoods in southern Africa: The case for non-timber forest products. Southern Forests, 70(3), 237-245.

Coomes, O. T., Barham, B. L., \& Takasaki, Y. (2004). Targeting conservation-development initiatives in tropical forests: insights from analyses of rain forest use and economic reliance among Amazonian peasants. Agricultural Economics, 51, 47-64.

Corbett, A., \& Daniels, C. (1996). Legislation and policies affecting community-based natural resources management in Namibia. Windhoek: Social Science Division University of Namibia.

Dercon, S., Hoddinott, J., \& Woldehanna, T. (2005). Vulnerability and shocks in 15 Ethiopian Villages, 1999-2004, BASIS CRPS, Department of Agricultural and Applied Economics, University of Wisconsin-Madison.

DFID. (1999). Sustainable livelihoods guidance sheets. Department of International Development. http:// www.livelihoods.org/info/info_guidancesheets.html

Ellis, F. (2000). Rural livelihoods and diversity in developing countries. Oxford: Oxford University Press.

Ellis, F., \& Freeman, H. A. (2004). Rural livelihoods and poverty reduction strategies in four African countries. Journal of Development Studies, 35(4), 1-30.

FAO. (2010). A system of integrated agricultural censuses and surveys. Italy: World Programme for the Census of Agriculture.

Fernández, A. (2010). Wildlife conservation in Zambia: Impact of game management areas on household welfare. Master of Science thesis, Michigan State University.

Filmer, D., \& Pritchett, L. H. (2001). Estimating wealth effects without expenditure data-Or tears: An application to educational enrollments in states of India. Demography, 38(1), 115-132.

Gbadegesin, A. (1996). Management of forest resources by women: A case study from the Olokemeji forest reserve area, southwestern Nigeria. Environmental Conservation, 23(2), 115-119.

Giess, W. (1998). A preliminary vegetation map of Namibia (3rd revised edition). Dinteria, 4, 1-112.

Government Gazette of the Republic of Namibia. (2001). Promulgation of Forest Act, 2001 (Act No. 12 of 2001). Windhoek, Namibia.

Government Gazette of the Republic of Namibia. (2005). Promulgation of Forest Act, 2005 (Act No. 13 of 2005). Windhoek, Namibia.

Harring, S. L., \& Odendaal, W. (2012). God stopped making the land-Land rights, conflict and law in Namibia's Caprivi Region. Land, Environment and Development Project. Legal Assistance Centre, Windhoek, Namibia.

Harrison, P. (1992). The third revolution: Population, environment and a sustainable world. Penguin, Harmondsworth.

Hsieh, H., \& Shannon, S. E. (2005). Three approaches to qualitative content analysis. Qualitative Health Research, 15(9), 1277-1288.

Jianchu, X., Fox, J., Vogler, J. B., Peifang, Z., Yongshou, F., Lixin, Y., et al. (2005). Land-use and landcover change and farmer vulnerability in Xishuangbanna Prefecture in Southwestern China. Environmental Management, 36(3), 404-413.

Jones, B. T. B. (2001). Results of a socio-ecological survey carried out in the Kavango Region, Namibia, May-August 2001. Unpublished report. Windhoek, Namibia.

Kalaba, F. K., Chirwa, P. W., Syampungani, S., \& Ajayi, O. C. (2010). Contribution of agroforestry to biodiversity and livelihoods improvement in rural communities of Southern African regions. In Teja Tscharntke, Christoph Leuschner, Edzo Veldkamp, Heiko Faust, Edi Guhardja, \& Arifuddin Bidin (Eds.), Tropical rainforests and agroforests under global change (pp. 461-476). Berlin: Springer.

Kasemir, B., Jaeger, C. C., \& Jager, J. (2003). Citizen participation in sustainability assessment. In B. Kasemir, C. C. Jager, J. Jager, \& T. M. Gardner (Eds.), Public participation and sustainability science (pp. 3-36). Cambridge: Cambridge University Press. 
LaFranchi, C. (1996). Small-scale and subsistence use of natural resources in Namibian communal areas. Report submitted to the World Wildlife Fund WWF-US) Living in a Finite Environment (LIFE) Program, Windhoek, Namibia.

Lambin, E. F. (1997). Modeling and monitoring land cover change processes in tropical regions. Progress in Physical Geography, 21, 375-393.

Maitima, J. M., Olson, J. M., Mugatha, S. M., Mugisha, S., \& Mutie, T. (2010). Land use changes, impacts and options for sustaining productivity and livelihoods in the basin of lake Victoria. Journal of Sustainable Development in Africa, 12, 3.

Mendelsohn, J., \& Roberts, C. (1997). An environmental profile and atlas of Caprivi. Ministry of Environment and Tourism, Directorate of Environmental Affairs, Windhoek, Namibia.

Mendelsohn, J., Jarvis, A., \& Robertson, T. (2009). Atlas of Namibia: A portrait of the Land and its people. Ministry of Environment and Tourism, Windhoek, Namibia.

Paumgarten, F., \& Shackleton, C. M. (2009). Wealth differentiation in household use and trade in nontimber forest products in South Africa. Ecological Economics, 68(12), 2950-2959.

Purvis, J. (2002). Fish and livelihoods: Fisheries on the eastern floodplains, Caprivi. DEA Research Discussion Paper, Windhoek, Namibia.

Rashid, D, A., Langworthy, M., \& Aradhyula, S. (2006). Livelihood shocks and coping strategies: An empirical study of Bangladesh households. Selected Paper prepared for presentation at the American Agricultural Economics Association Annual Meeting, Long Beach, California, July 23-26, 2006.

Sen, A. (1981). Poverty and famines: An essay on entitlement and deprivation. Oxford: Oxford University Press.

Shackleton, C., \& Shackleton, S. (2004). The importance of non-timber forest products in rural livelihood security and as safety nets: A review of evidence from South Africa. South African Journal of Science, 100(11-12), 658-664.

Shackleton, C. M., Shackleton, S. E., Buiten, E., \& Bird, N. (2007). The importance of dry woodlands and forests in rural livelihoods and poverty alleviation in South Africa. Forest Policy and Economics, 9 , $558-577$.

Shewmake, S. (2008). Vulnerability and the impact of climate change in South Africa's Limpopo river basin. International Food Policy Research Institute Discussion Paper 00804. http://www.ifpri.org/ pubs/dp/ifpridp00804.asp.

Simasiku, P., Simwanza, H. I., Tembo, G., Bandyopadhyay, S., \& Pavy, J. (2008). The impact of wildlife management policies on communities and conservation in game management areas in Zambia. Zambia: Natural Resources Consultative Forum.

Steimann, B. (2005). Livelihood strategies in north-west Pakistan. Results from the Sustainable Livelihoods Survey 2004, North-West Frontier Province (Pakistan) IP6 Working Paper No. 5.

Werner, W., \& Odendaal, W. (2010). Livelihoods after land reform: Namibia country report. Windhoek: Land, Environment and Development Project, Legal Assistance Centre. 